\title{
Business Strategy Recommendation for Permata 68 Minimarket in New Normal Regulation
}

\author{
Aryo Indra Djati \\ TANRI ABENG UNIVERSITY \\ Email: aidjati@tau.ac.id \\ Received: September $9^{\text {th }} 2020$ \\ Approved: October $28^{\text {th }} 2020$
}

\begin{abstract}
Retail consumption business, especially for mini market industry, its market share is very huge. Base on Association of Indonesian Retail Entreprenuer, for 2017, 2018, \& 2019 value of national sales on modern retail is around Rp.212 Trillion, Rp.233 Trillion \& Rp.270 Trillion. But the situation in 2020 is very difference due to new normal policy caused by the pandemic Covid-19. Indonesia Government implemented social and physical distancing or in Bahasa called by Pembatasan Sosial Berskala Besar (PSBB). Many activities should be performed from home, like working, scholl activities, and worship. But for business activites like minimarket that provide daily needs is still allow to open but with new protocols of new normal policy.
\end{abstract}

Due that PSBB policy, mini market industry is very competitive. There are big players who are leaders in the market such as Alfamart and Indomaret. Permata 68 minimarket is located at the main road not far from Halim Perdanakusuma Airport at East Jakarta. Permata 68 as a retail store with concept like minimarket that sell daily needs of household remain survive for last 14 years because have many customers who come from around store that very loyal and many of them are already shop since Permata 68 exist. Around its store are crowded civilian village and military housing complex. Direct competitor of Permata 68 is an Indomart store which is about $0,5 \mathrm{~km}$ from Permata 68 that existed since year 2013 and an Alfamart store which is about $0,4 \mathrm{~km}$ from Permata 68 that already existed since year 2010 .

Now competition between Permata 68 and big player in mini market industry more tighten. In order to win and sustain in a new normal policy, Permata 68 should have a strategy to win the battle of business competition of mini market and make good strategy to compete. Research in this research is set base on unclear business strategy of Permata 68. Shareholders is not pay attention about business strategy compare with direct competition with big player whom very aggressive to adapt with new normal policy. Permata 68 needs to make new strategy effectively by assessing the external and internal environmental situation. The result would to achieve is the effective and focused recommendation business strategy at the end of this research.

Keywords: Business Strategy, Minimarket, New Normal. 


\section{Introduction}

The Indonesian Economy shrink $5.32 \%$ year on year in second quarter 2020 where from the output side, trading shrink by $7.57 \%$. Daily needs of household always become priority for everyone to spent their money for. Basic needs goods like rice, sugar, cooking oil, instant noodle and others will always be required by the people. Demand of products are dominated by main contributor from food and beverages products. On the other hand, total minimarket in Indonesia for year 2017 is around 43.826 unit. Due that number of stores, minimarket industry is very competitive. There are big players who are leaders in the market such as Alfamart and Indomaret.

Permata 68 minimarket is located at the main road not far from Halim Perdanakusuma Airport at East Jakarta. Permata 68 store located in potential market. It is lying down at Halim Perdanakusuma main road that flanked by two crowded village that is Halim Perdanakusuma itself and Kebon Pala. Around that location, there are many Offices especially Indonesian Air Forces and also private and government related company that worked at Halim Perdanakusuma airport such as Angkasa Pura, airline company, freight company, travels and restaurants, flying schools, public schools and others.

Halim Perdanakusuma airport has now became atrractive place. Beside already surrounded by many population, since January 10, 2014 also serving commercial flight rather only just serving military, chartered, and flying school flight. Halim Perdanakusuma airport become alternative airport for civilian flight at Jakarta since Soekarno Hatta Airport cannot anymore to accommodate every international and domestic flight. Near Permata 68 store, there are 2 modern mini market with well known brand around Permata 68 store which is Alfamart and Indomaret. In order to win and sustain in a new normal policy, Permata 68 should have a strategy to win the battle of business competition of mini market and make good strategy to compete.

\section{Literature Review}

\section{PESTLE Analysis}

PESTLE stands for P - Political, E - Economic, S - Social, T - Technological, L - Legal, E Environmental. A PESTLE analysis is a framework or tool used by researchers to define, analyse and monitor the macro-environmental (external environment) factors that have an impact on an organisation or institutions with the purpose of using this information to guide strategic decision-making (Morrison, 2013). The result of which is used to identify threats and weaknesses which is used in a SWOT analysis, precisely on external analysis. After completing a PESTLE analysis, researcher should be able to use this to help identify and define the opportunities and threats for a SWOT analysis.

\section{Porter's Five Forces Analysis}

The "Five-Forces" model developed and created by Michael E. Porter has been the most commonly and usually used as an analytical tool by the researcher or analyst for examining the competitive environment and external analysis (Dess Lumpkin, 2014). It describes the competitive environment in terms of five basic competitive forces:

- The threat of new market entrants. 
- The bargaining power of buyer.

- The bargaining power of supplier.

- The threat of substitute products.

- The intensity of rivalry among competitors in an industry.

Porter's five forces analysis is very good to exercise the external situation of business organization connected with the condition of that organization itself.

\section{Diamond Strategy}

The five elements of strategy or diamond strategy was developed by strategy researchers Don Hambrick and Jim Fredrickson as a framework and tool for checking and communicating a strategy and analysis internal situation of business organization. If a business must have a strategy, then the strategy must necessarily have parts. What are those parts? A strategy has five elements, providing answers to five questions (Fredrickson, 2005) which is Arenas: where will we be active? Vehicles: how will we get there? Differentiators: how will we win in the marketplace? Staging: what will be our speed and sequence of moves? Economic logic: how will we obtain our returns?

\section{SWOT Analysis}

One of the most basic techniques for analyzing business firm and industry conditions is SWOT analysis. SWOT stands for strengths, weaknesses, opportunities, and threats. It provides "raw material" and significant information - a basic listing of conditions both inside and surrounding your company (Dess Lumpkin, 2014). The Strengths and Weaknesses refer to the internal conditions of the business firm - where your firm excels (strengths) and where it may be lacking relative to competitors (weaknesses). Opportunities and Threats are environmental conditions external to the business firm (Dess Lumpkin, 2014).

\section{Research Methodology}

Research methodology of this research is using qualitative descriptive method. The data were collected from primary and secondary sources. Primary data is obtained by interview with owner and employee of Permata 68. Secondary data is obtained from company study of Permata 68, books, and websites. This research is a case study of Permata 68 minimarket that performed with following framework: 


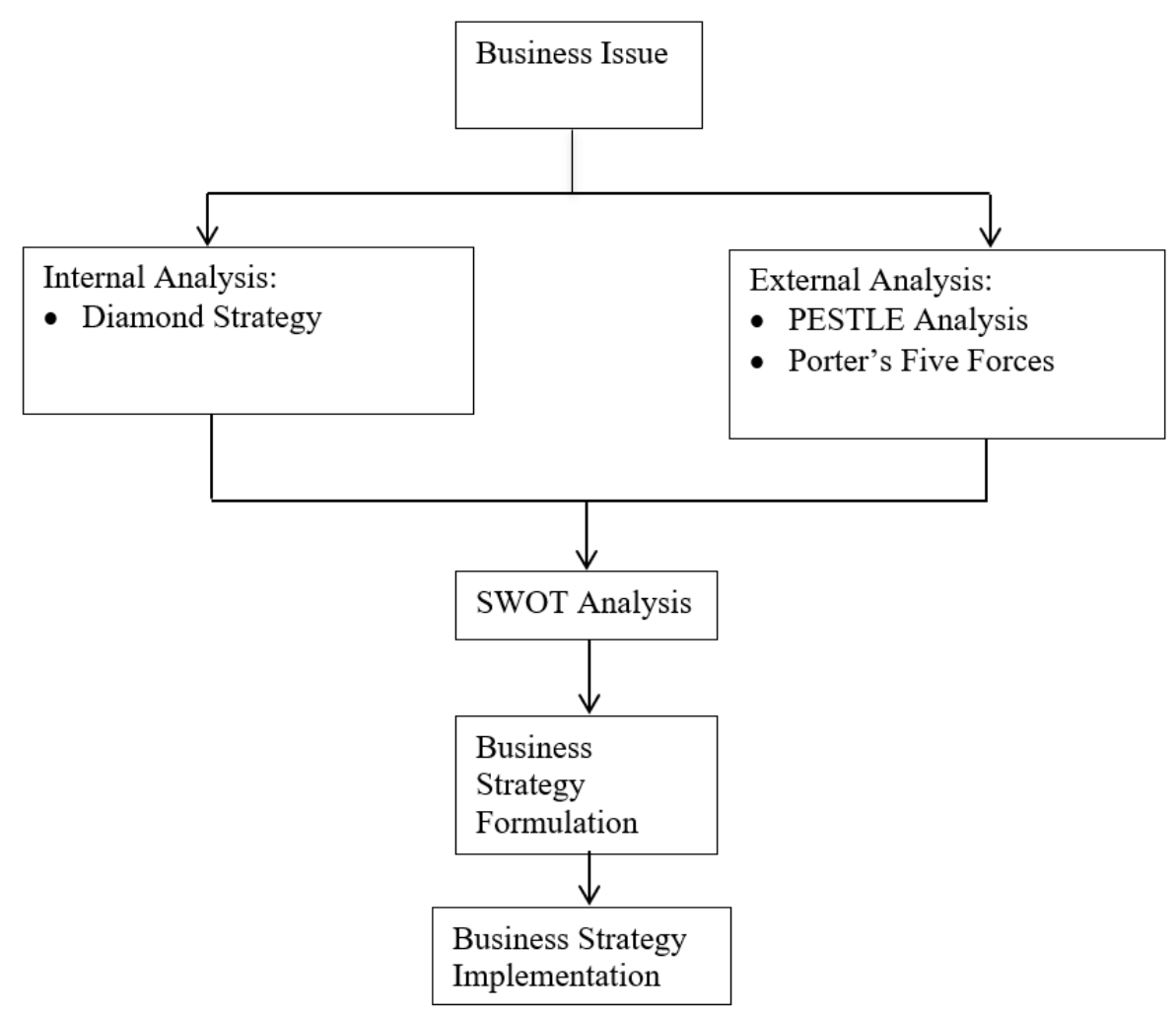

Figure 1 Conceptual Framework

The conceptual framework is used as guideline for the collection data and analysis activities for this research to define business strategy recommendation for Permata 68 in new normal policy. This framework also used for collection data where gathering facts from all stakeholder are important.

\section{Result}

\section{Critical Problems}

Based on the current situation from the exercise of some internal and external analysis, following are some critical problems of Permata 68:

- In people perspective, Permata 68 is still weak in the application of leadership include interpersonal leadership of each people. Permata 68 also less concern about soft skill on its employees.

- In part of marketing/ promotion, Permata 68 is weak in managing the various and creativity marketing/ promotion activities.

- Permata 68 is still weak on planning of expansion and open other store either planning for open a new one or buy an other existing store.

- Permata 68 in weak bargaining position to the suppliers/ vendors due to short account payable cycle.

- In revenue perspective, Permata 68 only has single cash generate model and not have many various model.

- In physical evidence, Permata 68 must concern about make up renovation.

- Permata 68 is less serious about making alliance with Inkopau to open another store. 
- Permata 68 has no passion to convert its conventional operation become online.

\section{Key Success Factors}

Based on that situation and conditions, Permata 68 should reposition and revised itself against new normal policy and its competitors in its current and future markets to maintain its market and loyal customers. To achieve that, following are the key success factors of Permata 68:

- People: Build strong leadership for all of people in the organization to lead themselves or others and to give more excellence services attitude every day for the customers and increase soft skill for each employees.

- Promotion:

- Make various type of promotion and marketing tools in addition to pamflet.

- Strenghten the relationship between existing customers and all employees.

- Staging: Shareholder of Permata 68 should seriously considering planning for open other store either through organic or anorganic growth.

- Suppliers: Permata 68 try to negotiate to the suppliers/ vendors to make term of payment longer than 14 days.

- Products: Permata 68 should make other cash generate model beside selling goods. Permata 68 can try to make dine in facility and using empty space for tenants in front of the store and provide payment services at the cashier.

- Physical Evidence: Permata 68 must provide its store with shop sign and sign pole that enough eye catching for whoever passing by its store. Permata 68 also can consider for doing renovation on its store.

- Vehicle: Permata 68 start to consider about make an alliances to support its expansion plan, specially to attract some investor to pay in IT investment.

\section{Company Generic Strategy Positioning}

Using the Porter's three generic strategies that a firm can use to overcome the five forces and achieve competitive advantage, types of generic strategy that fit with Permata 68 to win the competition is the combination of Cost Leadership and moderately Focus to loyal customers and institution related to Air Force institution.

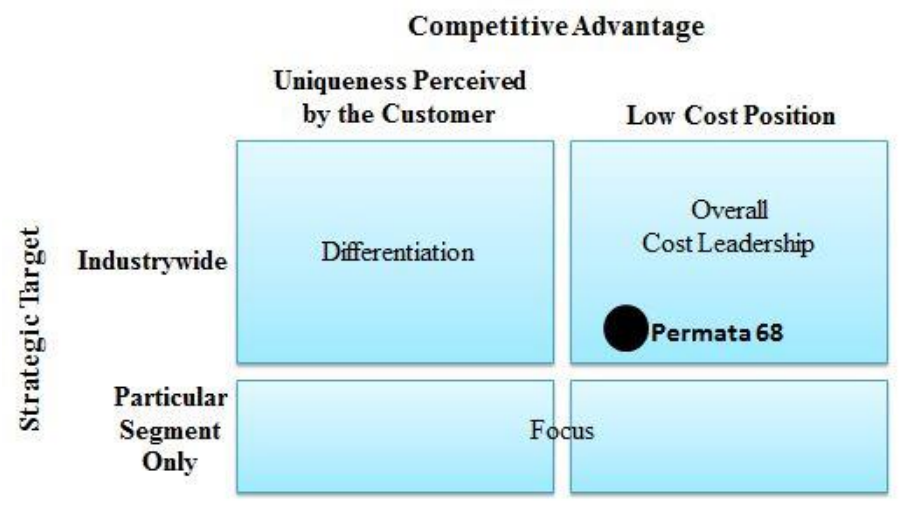

Figure 2 Permata 68 Position on Porter's generic strategy

\section{New Business Strategy}

From the strategic analysis that are described in previous chapter, the recommendation of new strategy for Permata 68 using strategy diamond model is give in figure below: 


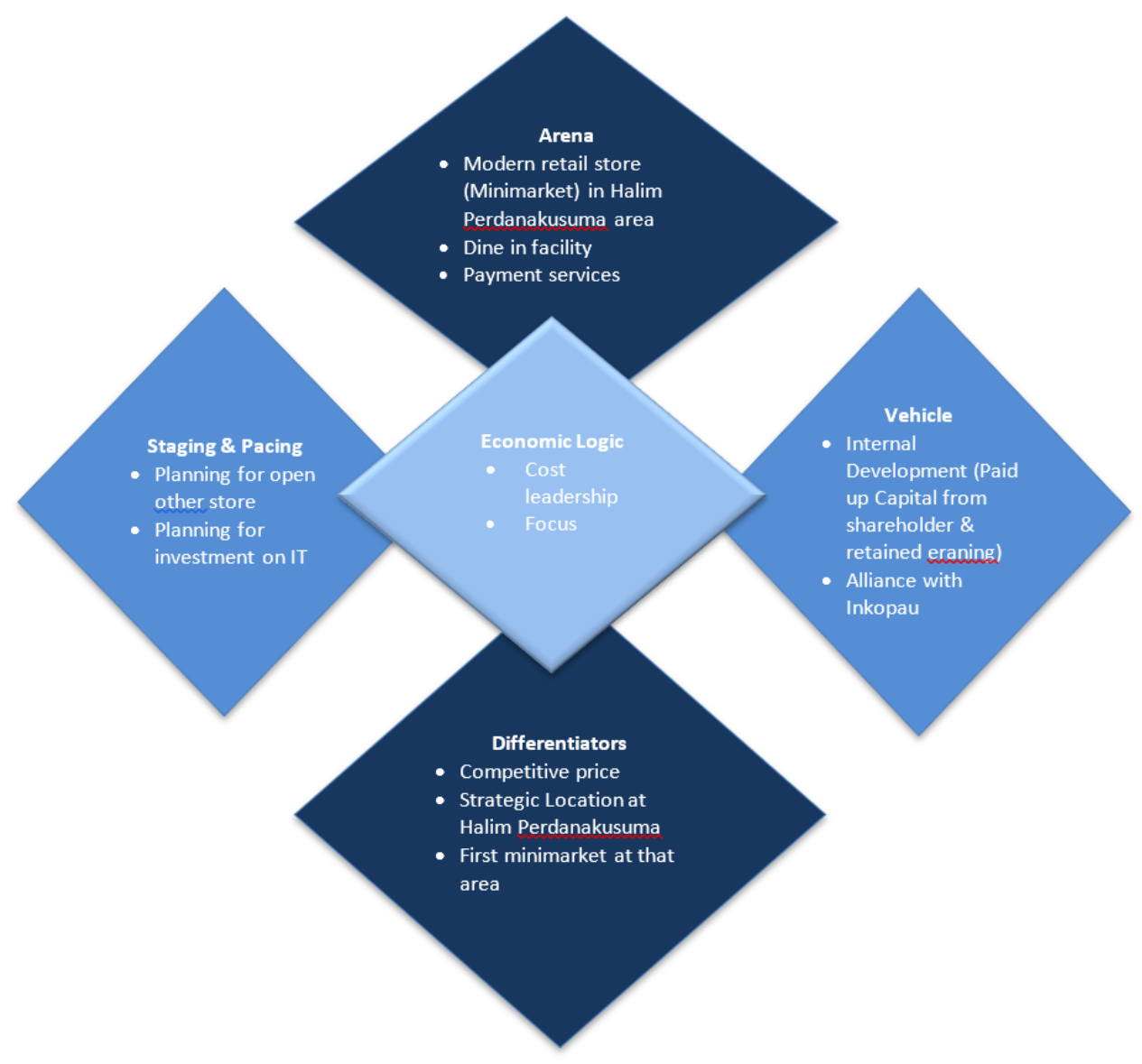

Figure 3 New Strategy Diamond Model of Permata 68

\section{Arena}

Permata 68 should maintain as modern retail store that sell household need in minimarket business model in Halim Perdanakusuma area. Permata 68 should maintain and focus through that area and maximize the good relationship with Indonesian Air Force Institution if Permata 68 want to open other store. Beside that Permata 68 should seriously consider about using empty space at its store to offer dine in facility for the customers. Others possible new service for Permata 68 is payment services facility like for PLN payment, KAI ticket, mobile phone voucher, cable TV, and etc.

\section{Vehicle}

Permata 68 should maintain its good internal development either from shareholder or from its revenue and retained earning. If possible all shareholder must inject another paid up capital for financed Permata 68 expansion. In other side, Permata 68 must start to make an alliances with Indonesian Air Force Cooperative (Inkopau) to joint together as a shareholder for expansion another store inside Air Force Military complex rather rent another unused asset to convert as minimarket that facing beuracracy and administration issues.

\section{Economic Logic}


Permata 68 still maintain with its cost leadership strategy and focus to the its customers especially loyal customers near its store. Since Permata 68 already has loyal customers and captive market from the community surrounding its existing store, so all employees must giving attention to always offering excellence service attitude and interpersonal leadership skill either for the customers itself or for each employees.

\section{Staging \& Pacing}

Permata 68 already right to plan an expansion for open another store either around its existing one or inside Military complex not far from its store. Permata 68 should seriously make it happen so the good name of brand Permata 68 in the community more strong and can survive in the competition with Alfamart and Indomaret. In 1-2 years from now at least, Permata 68 must open it either solely or make an alliances with Inkopau. Last, Permata 68 must plan to attract some investor to invest in IT system and consider to running also in online mode.

\section{Differentiators}

Permata 68 must strengthen its brand to the customers as a first modern retail store in minimarket concept for household daily need at Halim Perdanakusuma area with competitive price since 14 years ago. Maintain its loyal customers with excellence service attitude every day would be an advantage for the Permata 68 revenue.

\section{Conclusion and Recommendation}

\section{Conclusion}

The critical problems at Permata 68 are found in areas of product, people, promotion, physical evidence and some issues generate from strategy diamond model analysis which is staging, vehicle, and one issue from Porter's Five Forces analysis which is power of suppliers. Those aspects is then set as part of the key success factor of Permata 68 to be survive in current competition and win the future competition. Permata 68 in other side could maintain its focus and cost leadership strategies.

\section{Recommendation}

From the results of this research, the author recomends and suggest Permata 68 to implementate following activities:

- Keep focus to customers especially loyal customers and maintain cost leadership activities.

- Try to expand for Institution customers such as Air Force Institution and Airlines Corporation around Halim Perdanakusuma area.

- Provide all employees with training in class regularly at least one on every year. Training focused on service excellence and leadership and special training that needed on special purpose. Also increase on employees soft skills.

- Make various type of marketing and promotion activities such as give fund for support proposal that sent by the communities around Permata 68.

- Always reminder all employess to kept good interpersonal relationship with all customers especially for loyal customers and among each employees.

- All shareholders must seriously considering of doing expansion and make a clear timeline for open another store of Permata 68.

- Start to make an alliance with Inkopau to support its expansion plan. 
- Try to renegotiate with possible suppliers/ vendors about making term of payment longer than 14 days.

- Make another services like dine in facility for the customers and payment services at the cashier.

- Make big renovation on its store and equiped it with nice shop sign and sign pole. And provide Automated Teller Machine in its store.

- Try to attract some investor to pay investment on IT, so Permata 68 can running its operational by online.

\section{Implementation}

Implementation plan consist of business strategic recommendation and timeline to achieve the marketing strategy that aligned to Permata 68 business. Implementation plan divided into short term and long term programs.

\section{Short Term Program}

There are several activities for this short term implementation process:

1. Renegotiate with suppliers for longer term of payment.

2. Make renovation, shop sign, sign pole and provide Automated Teller Machine on its store.

3. Start to expand for Institution customer, provide payment service and dine in facility.

4. Start to give service training and proper training that needed for employees and enrich the employees with soft skill and uniform.

5. Make various type of promotion like sponsorship, and bundling products.

\section{Long Term Program}

There are several activities for this long term implementation process:

1. Maintain cost leadership activities combined with focus strategy.

2. Alliance with Inkopau or do it solely to open another store of Permata 68.

3. Keep focus giving excellence service on existing customers and remind for act as leadership for each employees.

4. Attract some investor to pay investment on IT for running operational by online.

\section{References}

\section{Books}

Christopher Lovelock, J. W. (2010). Services Marketing - People, Technology, Strategy (7th Edition). Prentice Hall.

Christopher Lovelock, L. W. (1999). Principles of Service Marketing and Management 2nd edition. New York: Prentice Hall.

Dess Lumpkin, E. M. (2014). Strategic Management. New York: McGraw-Hill Education.

Fredrickson, D. C. (2005). Are you sure you have a strategy? Dalam Academy of Management Executive (hal. 53). Academy of Management.

Morrison, M. (2013). Strategic business diagnostic tools: theory and practice. CreateSpace Independent Publishing. 
Philip Kotler, G. A. (2012). Principles of Marketing (14th Edition). New Jersey: Pearson Prentice Hall.

Porter, M. (1980). Competitive strategy: techniques for analyzing industries and competitors. New York: Free Press.

\section{Website}

https://bps.go.id/pressrelease/2020/08/05/1737/-ekonomi-indonesia-triwulan-ii-2020-turun-532-persen.html

https://ekonomi.bisnis.com/read/20190107/12/876089/2019-bisnis-ritel-modern-ditargettumbuh-10

https://ekonomi.bisnis.com/read/20200804/12/1274965/target-penjualan-ritel-modern-2020direvisi

https://jaktimkota.bps.go.id/publication/download.html?nrbvfeve=NjA5MTA0ZmRhYzkzN2 ZjZGU1ZjVhYzJh\&xzmn=aHR0cHM6Ly9qYWt0aW1rb3RhLmJwcy5nby5pZC9wdWJsaW NhdGlvbi8yMDE3LzA5LzI4LzYwOTEwNGZkYWM5MzdmY2RINWY1YWMyYS9rZWN hbWF0YW4tbWFrYXNhci1kYWxhbS1hbmdrYS0yMDE3Lmh0bWw\%3D\&twoadfnoarfeau f=MjAyMC0wOS0yOCAxMzoyNTo1MQ\%3D\%3D

https://marketeers.com/jumlah-minimarket-indonesia-terbanyak-di-asia-tenggara/ 